\title{
Rehabilitation Concepts for Multiple Knee Ligament Injuries
}

\author{
Gavril GHEORGHIEVICI ${ }^{1,2}$, Adriana Sarah NICA ${ }^{1,3}$, Brindusa MITOIU ${ }^{1,3}$, Delia CLANTAU ${ }^{1,3}$, Razvan \\ CISMASIU1,2, Emil HARITINIAN ${ }^{1,2}$, Cristian Ioan STOICA ${ }^{1,2}$
}

\begin{abstract}
Multiple knee ligament injuries represent a significant traumatic event with an important functional prejudice which involves the injury of at least two of the four major ligaments of the knee. Management of such injury requires a thorough assessment and an interdisciplinary approach. The rehabilitation program will be constructed in accordance to the severity of the lesion and the patients expectations. The higher the goals and a more pronounced injury will results in a higher degree of involvement from the rehabilitation team. In case of cruciate ligament injury associated with a collateral ligament injury the rehabilitation program is based mostly on the same principles as for a cruciate ligament intervention, with the first phase of the rehabilitation protocol being governed by an early protection phase due to the fact that early weight-bearing is considered a risk for later instability of the knee and influence over the healing tissue, while the second phase of protocol is characterised by gait restoration and maintaning balance and coordination. Multiple ligament injuries often necessitate longer rehabilitation periods, regaining full activity level being estimated at around 1 year post surgery. The purpose of the paper is to analyse the optimal modality of constructing a rehabilitation program for multiple ligament injuries and whether a consensus regarding protocol and procedures can be obtained.
\end{abstract}

Keywords: multiple ligament lesion, rehabilitation, protocol.

\section{Rezumat}

Leziunile ligamentare multiple de la nivelul genunchiului reprezintă un eveniment traumatic semnificativ, cu un prejudiciu funcțional important, ce implică lezarea a cel puțin două dintre cele patru ligamente ale genunchiului. Managementul unor astfel de leziuni necesită de cele mai multe ori o coordonare interdisciplinară. Programele de recuperare vor fi construite în funcție de gravitatea leziunii precum și de așteptările pacientului. Cu cât obiectivele sunt mai mari iar leziunile sunt mai accentuate, cu atat gradul de implicare din partea echipei interdisciplinare va fı mai ridicat. În cazul unei leziuni a ligamentului încrucișat anterior asociată cu o leziune de ligament colateral, programul de recuperare se bazează, în mare parte, pe aceleași principii ca cele pentru o intervenție a ligamentului încrucișat anterior, prima parte a protocolului de recuperare fiind reprezentată de o fază de protecție datorită faptului că încărcarea precoce reprezintă un risc pentru o posibilă instabilitate ulterioară a genunchiului și, implicit, o prelungire a perioadei de vindecare. A doua fază se caracterizează prin reluarea mersului, a coordonării și echilibrului. Leziunile ligamentare multiple necesită frecvent perioade mai lungi de recuperare, redobândirea unui nivel functional complet fiind estimată la aproximativ un an postoperator. Scopul lucrării este acela de a analiza modalitatea optimă de construire a unui program de recuperare și, in acelasi de timp, de a analiza existența unui consens privind protocolul și procedurile vizate.

Cuvinte cheie: leziuni ligamentare multiple, recuperare, protocol.

\footnotetext{
1 "Carol Davila" University of Medicine and Pharmacy, Bucharest Romania

2 "Foisor" Clinical Hospital of Orthopaedics, Bucharest, Romania

${ }^{3}$ National Institute of Rehabilitation, Physical Medicine and

Balneology, Bucharest, Romania
}

\section{Corresponding author.}

Gavril GHEORGHIEVICI, „Foisor" Clinical Hospital of

Orthopaedics, Bucharest, Romania.

E-mail: gavril.gheorghievici@gmail.com 


\section{BACKGROUND}

Multiple knee ligament injuries represent a significant traumatic event with an important functional prejudice which involves the injury of at least two of the four major ligaments of the knee. Management of such injury requires a thorough assessment and an interdisciplinary approach $^{1,2}$. The anterior cruciate ligament lesions appear when high forces are applied especially in actions such as pivoting or jumping ${ }^{3,4}$. The medial collateral ligament represents one of the most important stabilizers of the knee, which has a major role in supporting the knee against valgus stress, and also translational and rotational movement of the tibia ${ }^{5}$. Injuries of the ligament result most frequently from sport activities, falls or accidents and make for aprox. $40 \%$ of knee lesions according to some statistics ${ }^{6,7}$. The lesion can occur as a single injury, but it can be produced in association with other ligaments. When multiple ligament injuries are produced, usually the medial collateral ligament is associated with the injury of the anterior cruciate ligament, while the lateral collateral ligament injuries can be developed in combination with lesions of the posterior cruciate ligament ${ }^{8}$. Also, severe tear of the collateral ligament can intensify the load on the anterior cruciate ligament with 30 degrees of flexion according to some authors ${ }^{9}$. Mild lessions are often treated conservatory, with adapted rehabilitation programs, while more severe lesions require surgical treatment in order to improve functional outcome ${ }^{10}$.

Clinical examination represents an important stage in diagnosting ligament injuries, since the knee joint is more susceptible to injuries due to anatomical orientation and also due to its weight-bearing role. Examination must include the patient's history and clinical evaluation in order to not neglect any potential lesions, which otherwise overlooked could lead to a degenerative evolution of the knee because of the elevated shearing forces and high compression ${ }^{11}$. Multiple clinical tests are used in order to probe ligament integrity. Nonetheless, some authors have observed that the interpretation of these tests might be slightly inaccurate, because of the fact that there isn't a well established methodology, and also some studies have reported inconcludent figures regarding specificity, sensitivity and likehood ratios ${ }^{12}$. Lachman test and anterior drawer test are considered valuable means of evaluating ACL injuries. By some studies Lachman test presented low sensitivity compared to other tests, while other studies evidenced high sensitivity for both Lachman and drawer test (94.4\% vs. 93.3\%). Most frequent used test for the posterior cruciate ligament integrity are posterior drawer test, quadriceps active test or the posterior sag test. However, these evaluation tests remain subjective and are fundamented on the clinician's experience and interpretation ${ }^{13,14}$.

Although in most cases patients history and clinical examination can offer valuable information regarding ligament lesions, MRI investigation are necessary, and provide value especially when clinical diagnostic is difficult or uncertain, and offer evidence which further dictate the surgical or conservatory treatment. Possible complications of the surgical intervention may include tear or laxity of the graft, possible development of arthrofibrosis, hardware movement or deterioration ${ }^{15,16}$.

Nevertheless, even if surgical intervention is postponed, a rehabilitation program is necessary and should be team guided.The purpose of the paper is to analyse the optimal modality of constructing a rehabilitation program for multiple ligament injuries and whether a consensus regarding protocol and procedures can be obtained.

\section{MATERIAL AND METHOD}

We conducted a review of the literature using online databases PubMed, Embase, and Cochrane library by typing the following words: anterior cruciate ligament, ACL, posterior cruciate ligament, PCL, collateral medial ligament, rehabilitation, multiple ligament injury.

\section{RESULTS AND DISCUSSIONS}

The rehabilitation program will be constructed in accordance to the severity of the lesion and the patients expectations. The higher the goals and a more pronounced injury will results in a higher degree of involvement from the rehabilitation team. Setting realistic goals represents a fundamental part of the rehabilitation program, designing objective goals leading to better and specific outcomes, and will result in a higher patient satisfaction and an improved functional prognostic. The rehabilitation planning should also be measurable and time-related, in order to benefit from a better patient adherence, and should take into account the patients fear of unpredictability. This is why a permanent dialog between the rehabilitation specialist, orthopaedic surgeon and patient is necessary for goal attainment ${ }^{17,18}$.

In case of cruciate ligament injury associated with a collateral ligament injury the rehabilitation program is based mostly on the same principles as for a cruciate ligament intervention. The first phase of the reha- 
bilitation protocol is governed by an early protection phase. Weight bearing restrictions are maintained for the first 6 weeks post surgery, with the patient is being recommanded to wear a brace locked in extension ${ }^{19}$. One of the first objectives is quadriceps training, while teaching the patient to perform isometric pumps numerous times a day by using a towel placed under the leg. However, if the patient presents an evident quadriceps insufficiency, neuromuscular electrical stimulation can be added in order to increase muscle performance. Obtaining full knee extension is another objective of the first rehabilitation phase. This can be done by educating the patient to roll a towel under the ankle in order to facilitate gravitational forces to put the knee in extension ${ }^{20}$.

Plantar flexion exercises using a resistant band and straight leg raises can be added to the rehabilitation program in order to induce muscle strenghtening. A special attention needs to be put on the exercise of the hamstring muscles in order not to put too much pressure, in case the graft has been taken from that area ${ }^{21}$.

Phase two of the rehabilitation protocol is characterised by gait restoration, after the brace has been removed and the patient is able to realize a straight leg raise without hesitation. Advances in gait training will be done gradually, with first removing one crutch, and maintaining walking with a single crutch or the use of a cane, and then progress towards independent walking when the patient demonstrates a pain free ambulation and gait, and also the ability to execute a straight leg test without a $\operatorname{lag}^{22}$. In this phase of rehabilitation, aquatic therapy can be added to the program and especially ambulation on a water trendmill if permitted. According to AAOS guidelines, when the patient is able to perform 85 degrees of flexion, a $90 \mathrm{~mm}$ stationary bycicle can be added, in order to promote range of motion, and then will advence to a normal bycicle of $170 \mathrm{~mm}$ after achieving 115 degrees of flexion ${ }^{10,23}$.

In case of multiple ligament lesions, the rehabilitation program requires a higher degree of participation from both the pacient and the rehabilitation specialist, and also requires an interdisciplinary comunication with the orthopaedic surgeon. Multiple ligament injuries often necessitate longer rehabilitation periods, regaining full activity level being estimated at around 1 year post surgery. In this type of traumatic patients, a preoperative rehabilitation program is imperative, in order to functionally assess the patient and set optimal rehabilitation goals. The most demanding task in the rehabilitation protocol is finding an equilibrium betwe- en preserving the reconstruction graft but at the same time not developing stiffness to the operated knee ${ }^{24,25}$.

The first phase of the postoperative rehabilitation protocol is again dominated by the protection of the reconstructed tissues. Pain management and swelling prevention need to be addressed with the appliance of cryotherapy and maintaining an elevation of the lower extremity. Ice and compression should be applied at least 3 times a day for 20 minutes in the first postoperative weeks. Patient will only be allowed a toe-touch weight bearing in order to avoid loading on the operated knee. Also hip abduction and adduction sidelying are forbidden for 6 weeks in case of affected lateral or medial ligament. For patients with a reconstructed posterior cruciate ligament, active knee flexion is not permitted in order to avoid hamstring tension fireing ${ }^{26,27}$. Active assisted range of motion can be performed, but limited to 90 degrees of flexion. Patelar mobilisation is recommanded in the first days of the rehabilitation period. Knee extension must be emphasized in order to obtain proportionate extension to the non-operated leg. A continuous passive motion device can be applied in the first postoperative days for promoting range of motion. Progression criteria to the next rehabilitation phase must include mild to no effusion and minimal pain of the $\mathrm{knee}^{28}$.

The second phase of the rehabilitation program begins at 6 weeks post surgery and lasts until the end of the 12 week. This phase is primarly focused on increasing muscle strength and working on gait pattern in order to normalize gait. Balance exercises are gradually introduced and the patient will be headlined idea of ,gait cycle" in order to to better comprehend the mechanisms of walking ${ }^{26,29}$.

Knee symmetry for range of motion is expected to be obtained during this period. Soft tissue and patelar mobilisation are continued. Hip and core strenghtening are performed. Possibile muscle imbalances must be taken into account and corrected. Heel slides and wall slides are suggested. One of the principle precautions that needs to be taken into consideration is the appearence of arthrofibrosis in case the patient doesn't fully participate into the rehabilitation program. Once the patient has advanced to complete weight bearing, proprioception exercises are included. For patients who had a posterior ligament reconstruction, open chained exercises are forbidden for the first 12 postoperative weeks ${ }^{30,31}$.

When the patient has reached and maintained 90 degrees of flexion, two legged press can be performed. 
Once motor control in obtained, a crossover to single leg press can be produced. For patients with associated PCL injury, range of motion is limited to 60 degrees when working with a leg press. Stationary bicycle can be introduced in the rehab protocol at the moment when full range of motion has been obtained. After reaching 100 degrees of flexion, forward step up exercises are introduced, while step down exercises are being executed after reaching 120 degrees of flexion, using at the beggining a 4 inch /10 centimeters step. Progression is to be made to 6 inch $/ 15$ centimeters step when proper coordination is observed. Afterwards, an eliptical machine can be used ${ }^{10,32}$.

Progression criteria to the next rehabilitation phase will be based on the patients capacity to maintain a normal gait on all surfaces, a full range of motion on the operated knee and the ability to demonstrate and adequate leg control. A relevant kinetotherapy exercise for progressing is the patients ability to perform a step up and down single leg test with a good control ${ }^{33}$.

In the third phase of the rehabilitation program squats can be introduced, with an initial limited range of 45 degrees and then increase as the patient progresses into the rehabilitation program. On a first basis, wall squats are recommanded, and then advance to independent squats. The patient will continue to improve muscle strength and proprioception. Aquatic therapy can be introduced in this moment of the rehab period. Isolated hamstrings strenghtening exercises will also be associated. Patients will perform open chain kinetic exercises with progressive resistance. Balance training will advance to exercises on unstable surfaces ${ }^{34}$.

Final phase of the rehabilitation protocol starts at 20 weeks post surgery, and includes adding more demanding tasks and introducing sport related programs adapted to the patientțs individual functional level. It is the phase that includes running and plyometric exercises, agility drills and single leg squats. Return to sport activities must be made after a thorough evaluation of the knee regarding the possibility of reproducing all the involved sport movements without any signs of pain or inflammation, and the patient is able to demonstrate knee symmetry and similar quadriceps and hamstring muscle force. However, return to sport percentage is lower than return to work percentage according to some authors ${ }^{10,35,36}$.

Nonetheless, there are still many controversies regarding rehabilitation programs following multiple ligament injuries. The main cause is determined by the fact that it presents a relatively low incidence compared to single ligament injury, and therefor there isn't a sufficient amount of data and high quality evidence on the subject. On the other hand, surgical treament has proven to have statistically better outcome compared to conservative treatment, but there is still a lack of consensus regarding surgical procedure and optimal timing of the operation. Early weight-bearing is considered a risk for later instability of the knee and influence over the healing tissue. On the other side, this results in the patient not loading a significant amount of weight when given the indication of partial weight bearing as some studies have evidenced ${ }^{37}$. Controlled weight bearing results in better proprioception and favors correct muscle activity. The evolution of the rehabilitation program should be adapted in order to adress the operated structure that presents the slowest time period for healing or has higher chances of failing. This idea is empowered by biomechanical studies that have evidenced the need to restrain different muscle activities in order to protect vulnerable tissues ${ }^{38}$.

\section{CONCLUSIONS}

Multiple knee ligament injuries require an elaborate rehabilitation program which must harmoniously approach early mobilisation, weight bearing, adequate planning, muscle strenghtening and protection of the surgically treated structures in order to obtain a full return to daily activities and more endevour sport activities. Preoperative councelling and rehabilitation need to be taken into consideration, for proper treatment from the onset of the injury. Patient adherence plays a crucial role in order to optimise long term goals.

\section{ABBREVIATIONS}

AAOS American Academy of Orthopaedic Surgeons

ACL Anterior cruciate ligament

PCL Posterior cruciate ligament

MRI Magnetic resonance imaging

Compliance with ethics requirements: The authors declare no conflict of interest regarding this article. The authors declare that all the procedures and experiments of this study respect the ethical standards in the Helsinki Declaration of 1975, as revised in 2008(5), as well as the national law. Informed consent was obtained from all the patients included in the study. 
Rehabilitation Concepts for Multiple Knee Ligament Injuries

\section{References}

1. Bollen S. (2000). Epidemiology of knee injuries: diagnosis and triage. British journal of sports medicine, 34(3), 227-228.

2. Andrews, K., Lu, A., Mckean, L., \& Ebraheim, N. (2017). Review: Medial collateral ligament injuries. Journal of orthopaedics, 14(4), 550-554.

3. Merritt AL, Wahl CJ. Rationale and treatment of multiple ligament injured knees: the Seattle perspective. Oper Tech Sports Med, 2011, 19: 51-72.

4. Laprade R.F., Bernhardson A.S., Griffith C.J., Macalena J.A., Wijdicks C.A. Correlation of valgus stress radiographs with medial knee ligament injuries: an in vitro biomechanical study. Am J Sports Med. 2010;38:330-338.

5. Battaglia M.J., Lenhoff M.W., Ehteshami J.R. Medial collateral ligament injuries and subsequent load on the anterior cruciate ligament: a biomechanical evaluation in a cadaveric model. Am J Sports Med. 2009;37(2):305-311

6. Werner BC, Hadeed MM, Gwathmey FW, Jr, Gaskin CM, Hart JM, Miller MD. Medial injury in knee dislocations: what are the common injury patterns and surgical outcomes? Clin Orthop Relat Res. 2014;472(9):2658-2666.

7. Bispo, R. Z., Jr, Kawano, C. T., \& Guedes, A. V. (2008). Chronic multiple knee ligament injuries: epidemiological analysis of more than one hundred cases. Clinics (Sao Paulo, Brazil), 63(1), 3-8.

8. Irrgang JJ, Fitzgerald GK. Rehabilitation of the multiple-ligament-injured knee. Clin Sport Med. 2000;

9. Mook W.R., Miller M.D., Diduch D.R., Hertel J., Boachie-Adjei Y., Hart J.M. Multiple-ligament knee injuries: a systematic review of the timing of operative intervention and postoperative rehabilitation. J Bone Joint Surg Am. 2009;91:2946-2957.

10. Green A. Hayda R, Hecht A. Postoperative orthopaedic rehabilitation Wolters Kluwer 2018 ISBN-13: 978-1496360281

11. Seeber, G. H., Thalhamer, C., Hahne, J., \& Matthijs, O. (2018). Validation, Intrarater and Interrater Reliability Study of the LateralAnterior Drawer Test for Detecting Posterior Cruciate Ligament Ruptures: Study Protocol of a Prospective Controlled SingleBlinded Cross-Sectional Study. BMJ open, 8(5), e020999.

12. Hewett T.E., Noyes F.R., Lee M.D. Diagnosis of complete and partial posterior cruciate ligament ruptures:stress radiography compared with KT-1000 arthrometer and posterior drawer testing. Am. J. Sports Med. 1997;25:648-655.

13. Kopkow C Freiberg A Kirschner S Seidler A Schmitt J. Physical Examination Tests for the Diagnosis of Posterior Cruciate Ligament Rupture: A Systematic Review. J Orthop Sports Phys Ther. 2013;43(11):804-814.

14. Makhmalbaf, H., Moradi, A., Ganji, S., \& Omidi-Kashani, F. (2013). Accuracy of lachman and anterior drawer tests for anterior cruciate ligament injuries. The archives of bone and joint surgery, 1(2), 94-97.

15. Bien, N., Rajpurkar, P., Ball, R. L., Irvin, J., Park, A., Jones, E., Bereket, M., Patel, B. N., Yeom, K. W., Shpanskaya, K., Halabi, S., Zucker, E., Fanton, G., Amanatullah, D. F., Beaulieu, C. F., Riley, G. M., Stewart, R. J., Blankenberg, F. G., Larson, D. B., Jones, R. H., ... Lungren, M. P. (2018). Deep-learning-assisted diagnosis for knee magnetic resonance imaging: Development and retrospective validation of MRNet. PLoS medicine, 15(11), e1002699.

16. Nacey NC, Geeslin MG, Miller GW, Pierce JL. Magnetic resonance imaging of the knee: an overview and update of conventional and state of the art imaging. J Magn Reson Imaging. 2017;45:1257-75.

17. Scobbie L, Wyke S, Dixon D. Identifying and applying psychological theory to setting and achieving rehabilitation goals: development of a practice framework. Clin Rehabil. 2009; 23 (4): 321-333. ISSN 0269-2155.
18. Playford ED, Siegert R, Levack W, Freeman J. Areas of consensus and controversy about goal setting in rehabilitation: a conference report. Clin Rehabil. 2009. 23(4): 334-344.

19. Burrus MT, Werner BC, Griffin JW, Gwathmey FW, Miller MD. Diagnostic and management strategies for multiligament knee injuries: a critical analysis review. JBJS Rev. 2016;4(2).

20. Peskun CJ, Whelan DB. Outcomes of operative and nonoperative treatment of multiligament knee injuries: an evidence-based review. Sports Med Arthrosc. 2011;19(2):167-173.

21. Buyukdogan, K., Laidlaw, M. S., \& Miller, M. D. (2018). Surgical Management of the Multiple-Ligament Knee Injury. Arthroscopy techniques, 7(2), e147-e164.

22. Kim S.J., Kim S.H., Jung M., Kim J.M., Lee S.W. Does sequence of graft tensioning affect outcomes in combined anterior and posterior cruciate ligament reconstructions? Clin Orthop Relat Res. 2015;473:235-243.

23. Angelini F.J., Helito C.P., Tozi M.R. Combined reconstruction of the anterior cruciate ligament and posterolateral corner with a single femoral tunnel. Arthrosc Tech. 2013;2:e285-288.

24. Tzurbakis M, Diamantopoulos A, Xenakis T, Georgoulis A. Surgical treatment of multiple knee ligament injuries in 44 patients:2-8 years follow-up results. Knee Surg Sports Traumatol Arthosc. 2006;14:739-49.

25. Manske RC, Prohaska D. Physical examination and imaging of the acute multiple ligament knee injury. N Am J Sports Phys Ther, 2008, 3: 191-197.

26. Sun, L., Wu, B., Tian, M., \& Luo, Y. Z. (2016). Results of multiple ligament injured knees operated by three different strategies. Indian journal of orthopaedics, 50(1), 43-48.

27. Hirschmann MT, Zimmermann N, Rychen T, Candrian C, Hudetz D, Lorez LG, et al. Clinical and radiological outcomes after management of traumatic knee dislocation by open single stage complete reconstruction/repair. BMC Musculoskelet Disord. 2010;11:102.

28. Moulton SG, Cram TR, James EW, et al. The supine internal rotation test: a pilot study evaluating tibial internal rotation in grade iii posterior cruciate ligament tears. Orthop J Sports Med 2015;3 10.1177/2325967115572135

29. Helgeson MD, Lehman RA, Jr, Murphy KP. Initial evaluation of the acute and chronic multiple ligament injured knee. Am J Knee Surg. 2005;18:213-9.

30. Levy B.A., Dajani K.A., Morgan J.A., Shah J.P., Dahm D.L., Stuart M.J. Repair versus reconstruction of the fibular collateral ligament and posterolateral corner in the multiligament-injured knee. Am J Sports Med. 2010;38:804-809.

31. Lasmar RC, Marques de Almeida A, Serbino JW, Jr, Mota Albuquerque RF, Hernandez AJ. Importance of the different posterolateral knee static stabilizers: biomechanical study. Clinics. 2010;65(4):433-440.

32. Zhang, Y., Zhang, X., Hao, Y., Zhang, Y. M., Wang, M., \& Zhou, Y. (2013). Surgical management of the multiple-ligament injured knee: a case series from Chongqing, China and review of published reports. Orthopaedic surgery, 5(4), 239-249.

33. Strobel MJ, Schulz MS, Petersen WJ, Eichhorn HJ. Combined anterior cruciate ligament, posterior cruciate ligament, and posterolateral corner reconstruction with autogenous hamstring grafts in chronic instabilities. Arthroscopy. 2006;22:18292.

34. Scheck, J., Chakraborty, A., \& Zimmermann, G. (2020). Arthroscopic suture bracing of posterior cruciate ligament in a multiple ligament knee injury - A technical report. Trauma case reports, 25, 100279.

35. Dephillipo, n. n., Berning, k., \& Laprade, r. f. (2020). Multi-ligament knee reconstruction and novel meniscus radial repair te- 
Gavril GHEORGHIEVICI et al.

chnique, with return to olympic level skiing: a case report. international journal of sports physical therapy, 15(1), 139-147.

36. Arundale AJH Capin JJ Zarzycki R Smith A Snyder-Mackler L. Functional and patient-reported outcomes improve over the course of rehabilitation: A secondary analysis of the ACL-SPORTS Trial. Sports Health. 2018;10:441-452.

37. Lynch, A. D., Chmielewski, T., Bailey, L., Stuart, M., Cooper, J., Coady, C., Sgroi, T., Owens, J., Schenck, R., Whelan, D., Musahl,
V., Irrgang, J., \& STaR Trial Investigators (2017). Current Concepts and Controversies in Rehabilitation After Surgery for Multiple Ligament Knee Injury. Current reviews in musculoskeletal medicine, 10(3), 328-345.

38. Markolf KL, O'Neill G, Jackson SR, McAllister DR. Reconstruction of knees with combined cruciate deficiencies: a biomechanical study. J Bone Joint Surg Am. 2003;85:1768-1774. 